\title{
RAPELD: A MODIFICATION OF THE GENTRY METHOD FOR BIODIVERSITY SURVEYS IN LONG-TERM ECOLOGICAL RESEARCH SITES.
}

\author{
William E. Magnusson, Albertina P. Lima, Regina Luizão, Flávio Luizão, Flávia R. C. Costa, Carolina Volkmer de \\ Castilho and V. F. Kinupp.
}

Biota Neotropica v5 (n2) - http://www.biotaneotropica.org.br/v5n2/pt/abstract?point-of-view+bn01005022005

Date Received 09/17/2004

Revised 06/26/2005

Accepted 07/01/2005

Instituto Nacional de Pesquisas da Amazônia, Caixa Postal 478, 69011-970 Manaus AM, Brazil. Corresponding author: Flávia Costa, INPA/CPEC, CP 478, 69011-970 Manaus AM, Brasil.

Email: anfe@inpa.gov.br.Tel.: 6431834.Fax:6421909.

\begin{abstract}
Our objectives were to develop a method that would be appropriate for long-term ecological studies, but that would permit rapid surveys to evaluate biotic complementarity and land-use planning in Amazonia. The Amazon basin covers about 7 million $\mathrm{km}^{2}$. Therefore, even a sparse coverage, with one sample site per $10.000 \mathrm{~km}^{2}$, would require about 700 sampling sites. Financial considerations limit the number of sites and investment at each site, but incomplete coverage makes evaluation of biotic complementarity difficult or impossible (Reddy \& Dávalos 2003). Our next challenge is to install similar systems throughout Amazonia. The cost, based on modification of Al Gentry's original design is moderate (less than US\$ 50.000 per site if it is not necessary to immediately identify all vascular plants in plots) and we can obtain RAP results for most taxa in the short term at much lower cost. However, biological surveys will only be relevant if the local people participate and the surveys serve as much to teach the local communities about the value of their natural resources as they serve to teach the international community about biodiversity. Therefore, we want to see each site run as a long-term ecological research project by local people and institutions. Biological surveys are an important tool in land-use planning, but only the local people can implement those plans.
\end{abstract}

Key words: Tropical forest, inventory, plot size, plot shape, biotic complementarity, survey, land-use planning.

\section{Resumo}

Este estudo descreve uma modificação do método de parcelas de 0.1 ha desenvolvido por Gentry, que nós adaptamos para sítios de pesquisa ecológica de longa-duração na Amazônia brasileira. Nosso objetivo foi desenvolver um método que fosse apropriado para pesquisas ecológicas de longa-duração (componente PELD), mas que permitissem inventários rápidos para avaliação da complementaridade biótica e planejamento do uso da terra na Amazônia (componente RAP). A filosofia por trás do método é a de maximizar a probabilidade de amostrar adequadamente as comunidades biológicas, para o que são necessárias áreas amostrais grandes, e ao mesmo tempo minimizar a variação nos fatores abióticos que afetam estas comunidades, o que requer amostragem de áreas pequenas. Para conseguir isto, as parcelas são longas e estreitas, com seu maior eixo orientado ao longo das curvas de nível do terreno. Este desenho minimiza a variação interna de topografia e solo em cada parcela, e permite o uso destas variáveis como preditoras das distribuições de espécies. O desenho pode ser usado para vários taxa e estágios de vida, ajustando a largura da parcela ou distribuindo sub-amostras ao longo da parcela. As parcelas são distribuídas sistematicamente em uma grade de trilhas, que é usada para amostrar taxa que não podem ser amostrados em parcelas pequenas. Cada grade de trilhas e parcelas constitui um sítio de pesquisa. A distribuição sistemática de parcelas na paisagem permite estimativas não tendenciosas da distribuição, abundância e biomassa das espécies em cada sítio, e comparações biogeográficas entre sítios. Os custos de implementação são moderados, considerando a grande produção gerada pelos estudos integrados.

Palavras-chave:Floresta tropical; inventário; planejamento do uso da terra; tamanho de parcela; forma de parcela; complementaridade biológica; amostragem. 
Phillips et al. (2003) explained many of the advantages of 0.1 ha plots in comparison with 1 ha plots for floristic surveys, and lamented the fact that many of the 0.1 ha plots were not marked for long-term studies. Here we describe a modification of the 0.1 ha survey method developed by Gentry (1982) that we adapted for long-term ecological sites in the Brazilian Amazon. There is no single best method appropriate for all questions, but other researchers may benefit from our experience in central Amazonia.

Our objectives were to develop a method that would be appropriate for long-term ecological studies, but that would permit rapid surveys to evaluate biotic complementarity and land-use planning in Amazonia. The Amazon basin covers about 7 million $\mathrm{km}^{2}$. Therefore, even a sparse coverage, with one sample site per $10.000 \mathrm{~km}^{2}$, would require about 700 sampling sites. Financial considerations limit the number of sites and investment at each site, but incomplete coverage makes evaluation of biotic complementarity difficult or impossible (Reddy \& Dávalos 2003).

Our modification of the Gentry method consists of orienting the long axis of individual plots along the isocline, using different widths of plot for different taxa, and distributing the plots regularly across the landscape to be sampled. In each site, a grid of regularly spaced north-south and east-west trails is established to access the plots, and allow inclusion of taxa that cannot be sampled in small plots. Each of these modifications has costs and benefits, but the whole system has many advantages over conventional methods.

Land-use planning requires information on biotic complementarity among sites (Margules \& Pressey 2000). At the scale of the Amazon basin (or country, or state), each site is a compound plot, and the smaller sampled units are subplots. For long-term ecological studies within sites, each sampled unit is a plot. Here, we will refer to the whole site as the "plot system", and to individual units as "plots”. Ecological studies within sites are relatively easy to interpret. Ecological studies using individual plots from different plot systems are more complicated, because differences among sites also reflect historic and large-scale biogeographic effects that may have little to do with present ecological processes.

The name for the method derives from the two scales it has to accommodate. For comparisons among sites, we need rapid assessments, such as the RAP surveys carried out by Conservation International. To understand ecological processes within sites, we need long-term ecological research (LTER) sites. The Brazilian acronym for LTER is PELD; hence the name for the method, RAPELD.

To date, we have implemented the method at only one site, Reserva Florestal Adolpho Ducke (Reserva Ducke), on the outskirts of Manaus, Amazonas, Brasil (02 ${ }^{\circ} 55^{\prime} \mathrm{S}$, 5959' W), but the method has been adopted for the Programa de Pesquisa em Biodiversidade (a program of the Brazilian
Ministry of Science and Technology) in the Amazonian Biome, and at least 4 more sites will be implemented in 2005. The Reserva Ducke site has topography, vegetation structure, climate and soils that are typical of much the lowlands in the Amazon Basin. The plot system covers $64 \mathrm{~km}^{2}$, but we made the initial plot system larger than we will use in subsequent sites (probably $25 \mathrm{~km}^{2}$ ) so that we could evaluate the effect of site coverage on complementarity. Even $64 \mathrm{~km}^{2}$ is a very small proportion of the $10.000 \mathrm{~km}^{2}$ area it would have to represent if we realize our dream of 700 sites distributed uniformly across the Amazon basin.

The size, shape and orientation of plots often determine the questions that can be answered (e.g. Caughley \& Sinclair 1994, Stern 1998, Magnusson \& Mourão 2004). For ecological studies of plants, square 1 ha plots have limited utility because each plot potentially contains a huge range of soil conditions and topography, making it difficult to discern ecological relationships (Phillips et al. 2003). Some researchers only place plots on relatively flat areas, but this results in a biased sample of the site. Long thin plots may contain less topographic variation because they only capture gradients in one direction. However, they may still cover a variety of ecological conditions. In Amazonia, soil types generally coincide largely with altitude, so long thin plots oriented along isoclines tend to be relatively homogeneous in soil conditions. This may not be so in areas subject to strong faulting and distortion of sedimentary layers. Tuomisto et al. (2003) oriented plots down slopes. This increased the variability within plots, which is useful if a single plot has to represent the region. However, because of this, those authors could not evaluate the direct effects of topographic variables, and only evaluated whether vegetation variability reflected topographic variability.

We use long (250 m), thin (width variable depending on taxa or life stage) plots that follow isoclines. Plots that snake along isoclines are harder to implement than rectangular plots, such as those used by Gentry, and more care is needed in determining whether an individual organism is within the plot or not. In two cases at Reserva Ducke, plots were on small knolls and doubled around onto themselves. We just extended the plot to account for the area of overlap, but randomly choosing another starting point nearby would also be a viable alternative. Surveys of organisms are so imprecise that we do not worry about a possible small error in about 3\% of our plots.

As the plot follows the isocline, variation in altitude within the plot is negligible. This allows inclusion of altitude as a predictor variable. Although altitude per se probably does not directly affect the organisms (variation within most of lowland Amazonia is less than $150 \mathrm{~m}$ ) it is related to many other edaphic characteristics which may directly affect organisms, and is easily retrieved from maps or satellite images. In Reserva Ducke, altitude and inclination in our plots account for about $30 \%$ of the variation in above-ground biomass (Castilho 2004). 
Another advantage of following the isocline is that the length of the plot is exactly that which would be captured on a satellite image or transferred to a map. Plots with straight sides that cut across vertical variation in topography do not have the same linear dimensions measured along the edge of the plot at ground level and seen by a satellite in plan view. Most extrapolations of habitat categories or sampled areas are based on maps, which do not take into account the effect of topographic irregularities on the surface area included. The width of our plots was measured horizontally (map distances), which is logistically difficult for the largest widths (42 m). Although the ground and map distances are identical along the long axis of our plots, they are different when measured across the long axis.

Most researchers are not specific about whether they used map areas or ground-surface areas in their studies. Researchers who use small plots rarely if ever correct for slope. Researchers who use larger plots may correct for the effects of slope on map areas, but rarely report the correction. In our plots, mean slope across the plot ranged from 0 to $27.8^{\circ}$. This means that plots would effectively sample up to $13 \%$ more ground area than the map area indicates if areas were measured on the ground surface.

The original design by Gentry did not include an access trail because long-term monitoring was not a primary aim of the original studies. As our plots are designed to be used by many researchers in long-term ecological studies, it is important to minimize trampling and other effects of researcher presence. Access to our plots is via $2 \mathrm{~m}$ wide trails along the long (250 $\mathrm{m}$ ) axis of the plots. This area can also be used for destructive activities, such as soil sampling, suspended litter collectors, and pit-fall traps.

The Gentry plots have fixed width (presumably, but not stated in the original papers, this refers to ground width rather than map width). However, the logistical difficulties increase with the width of the plot. Our objective is always to make the width of the plot as narrow as feasible without sacrificing precision. Understory herbs are recorded in a plot $2 \mathrm{~m}$ wide, giving a plot size of 0.05 ha. Shrubs and trees with diameter at breast height (DAP) e" $1 \mathrm{~cm}$ are recorded in a plot $4 \mathrm{~m}$ wide (2 $\mathrm{m}$ on each side of the central trail), giving a plot size of 0.1 ha. Trees with DAP e” $10 \mathrm{~cm}$ are measured in a plot $20 \mathrm{~m}$ wide (10 m each side of the central trail), giving a plot size of 0.5 ha for trees in this size range. Trees with DAP $>30 \mathrm{~cm}$ are measured in a plot of $40 \mathrm{~m}$ width (20 m each side of the central trail), giving a plot size of 1 ha for larger trees.

Other organisms, life stages and functional groups are measured in plots or subsamples that are even narrower than those used for plants. Some leaf-litter lizards are surveyed in plots with width $<1 \mathrm{~m}$, and the soil mesofauna is recorded in plots that are essentially the width of the soil corer. However, all organisms are sampled along the entire
$250 \mathrm{~m}$. Surveying very abundant organisms over wide areas is extremely inefficient, and reduces the precision with which environmental variables, such as soil texture or humidity, can be measured. Wide plots should only be used for organisms such as large trees that cannot be effectively sampled in small areas, unless the study includes thousands of plots (e.g. Clark et al. 1999). Any sampling scheme has to take into account the trade off in precision of documenting the biotic assemblage (usually higher in large plots), and the precision of measuring environmental variables (usually higher in small plots).

The precision of measurements of environmental variables is less for large or mobile organisms that need to be sampled in wide plots than for organisms that can be sampled in narrow plots. However, it is unrealistic to expect these organisms to have precise relationships with environmental variables. Mobile organisms will encounter a wide range of conditions within a short period, and large trees will have extensive root systems that sample a much wider range of altitudes and soil conditions than do the roots of smaller organisms, such as herbs. These considerations should be taken into account in analyses, but no sampling system can completely eliminate differences between species that operate on different spatial or temporal scales.

Gentry plots have been used to describe variation within and between geographic areas. However, there is much small-scale $(1-10 \mathrm{~km})$ beta diversity in tropical forest vegetation, even within vegetation "types”, such as terra firme forest (Clark et al. 1999, Phillips et al. 2003, Tuomisto \& Ruokolainen 1994, Vormisto et al. 2000, Tuomisto et al. 2003). Therefore, the area sampled for inter-site comparisons needs to be large. Small plots ( $1-50$ ha) capture a very small part of the species diversity of the site for many taxonomic groups. This is the principal reason that many 0.1 ha plots are so much more efficient to capture the site diversity than 1 ha plots with the same total area (Phillips et al. 2003). For inter-site comparisons, we consider the plot system to represent a single compound plot consisting of many subplots.

It is important to emphasize the conceptual difference between plot systems (sites) and plots. Only plots are inventoried, and only for some size classes of some taxonomic or functional groups. An inventory is a complete count, such as that made of stock in a shop, or forestry coupes where all commercially valuable trees are marked. Where site is the unit, neither a single small plot, nor many smaller plots, result in an inventory of the site. They simply represent samples with many false absences (Hirzel et al. 2002, Nichols et al. 1998). For biogeographical or land-use planning analyses the term "inventory" is misleading.

If the objective is to describe the variability within sites, the plot system has to cover the whole site. If the objective is to compare sites, the pattern and spacing of 
plots within plot systems has to be similar between sites. At the Reserva Ducke site, we distributed plots homogeneously over a $64 \mathrm{~km}^{2}$ grid of trails spaced $1 \mathrm{~km}$ apart, resulting in 72 plots with a minimum distance of $1 \mathrm{~km}$ between them. This homogeneous distribution is useful to map the distribution of taxa within the site. For some analyses, a random distribution could be theoretically advantageous, but distributing plots randomly across such a large area would be a logistical nightmare. The trail system, with numbered PVC stakes, and measured altitude, each $100 \mathrm{~m}$ along the trail, was installed by a professional topographer at a total cost of about US\$20,000. The system which will be used by PPBio, with the complete installation of a $25 \mathrm{~km}^{2}$ grid and 30 plots is estimated to cost US\$17.000 or R\$50.000.

We will illustrate some of the advantages of a plot system that covers the whole site using data for species of the understory genus Psychotria (Rubiaceae) that have been sampled in 61 of our plots at Reserva Ducke by V. Kinupp. A detailed analyses of these data will be presented elsewhere (Kinupp \& Magnusson, in press). The flora of Reserva Ducke has been studied more intensively than most tropical sites and a detailed guide to the flora is available (Ribeiro et al. 1999). The field guide was the result of detailed studies carried out over $5 y$ in about $20 \%$ of the reserve that cost in excess of 1 million dollars. Although the studies covered only about $20 \mathrm{~km}^{2}$, this is an area many orders of magnitude greater than most tropical-forest plots.

The Ducke Flora project was an intensive inventory of vascular plant species by 25 local botanists and many international collaborators. Most data for the Projeto Flora were obtained between 1994 and 1998 in the northwest corner of the reserve, where there was a network of trails (Ribeiro et al. 1999). Eighteen of the plots surveyed by V. Kinupp in this study overlapped the area investigated intensively by the Projeto Flora project (Ribeiro et al. 1999). This allowed a test of the effectiveness of the Projeto Flora surveys, and an estimate of the efficiency of V. Kinupp at finding species of Psychotria using the double survey estimate (Magnusson et al. 1978).

Eighteen of our plots within $1 \mathrm{~km}$ of the trail system used by the Projeto Flora were assumed to have been within the sampling area of the Projeto Flora. Within this area, species were listed as being encountered only by the Projeto Flora, only by our surveys, or by both surveys. The total number of species in the reserve was estimated by multiplying the total number found in our surveys, by the inverse of the estimate of V. Kinupp's sampling efficiency in the intensively surveyed area.

In the area surveyed by the Projeto Flora, V. Kinupp registered 17 of the 27 species found by the Projeto Flora (Ribeiro et al. 1999), but did not find any species that were not encountered by the Projeto Flora team. Assuming that the Projeto Flora did not register any species of Psychotria that were detected only outside this area, this indicates that the intensive searches by the Projeto-Flora team in approximately $20 \%$ of the reserve were sufficient to encounter most or all of the species of Psychotria there. That is, the Projeto Flora apparently inventoried the species of Psychotria in that area. In contrast, the less intensive surveys used in this study revealed only about $63 \%$ of the species present in that area. Based on that estimate of sampling efficiency, and that V. Kinupp encountered 24 species in his survey of the whole reserve (including species found in travel between plots), we estimate that a survey as intensive as that used by the Projeto Flora over the whole reserve would find about $24 / 0.63=38$ species in the reserve. If some of the species registered by the Projeto Flora were only encountered outside the $20 \mathrm{~km}^{2}$ area, the estimate of the number of species in the reserve would be even higher.

We do not believe that many areas in Amazonia will be sampled as intensively as that surveyed by the Projeto Flora, and at over 1 million dollars per site, it would cost close to 1 billion dollars to survey our goal of 700 sites at that intensity, just for vascular plants. Even at that intensity, the Projeto Flora failed to record at least $25 \%$ of the species of Psychotria that occur within the apparently homogeneous forest within $7 \mathrm{~km}$ of the site. We believe that, rather than attempting to inventory the flora of Amazonia, it will be much more productive to sample the flora using a standardized protocol that is able to detect mesoscale variation in species occurrences, and analyze the data using methods that are little affected by false absences (e.g. Reyers et al. 2002).

Mantel tests indicate that the species composition of Psychotria in Reserva Ducke plots is spatially autocorrelated out to distances of about $4 \mathrm{~km}$, but environmental variables, such as soil texture and altitude, are not spatially autocorrelated for plots $1 \mathrm{~km}$ apart. Therefore, ecological studies in Reserva Ducke relating species composition to environmental variables in these plots do not have to take into account the spatial autocorrelation. Plots placed closer together would almost certainly show spatial autocorrelation in the environmental variables and this would complicate ecological analyses (Meot et al. 1998). Even with 1 km between plots, the information on species composition of Psychotria is not independent of information collected in neighbouring plots. Therefore, even more widely spaced plots would probably be more efficient for collecting information on site assemblage structure to be used in biogeographical analyses. Other taxa may show spatial autocorrelation to even greater distances. However, we do not believe that it would be viable to investigate many sites with a plot system at each site covering more than $25 \mathrm{~km}^{2}$.

Although Al Gentry used long thin plots mainly to sample plants, we have found them to be extremely useful for many other organisms. We have sampled many taxa in our permanent plots, including microbial biomass, soil mesofauna, ants, frogs, lizards, herbs, shrubs and trees, and 
most of these collections can be done by students because of the ease of access and the supplementary data on environmental variables that are already available. Although we had to use a separate system of permanent plots for stream organisms (Mendonça 2002), the aquatic plots are all accessible from the trail system. In the future, the standardized sampling of many taxa will allow studies of covariation among different taxa and possibly the identification of surrogates for biogeographical analyses.

Many of the organisms with which tropical biologists are concerned cannot be sampled in plots. However, the plot data are often useful for describing habitat and determining how and why more mobile organisms use the landscape. Therefore, it is important that plots be integrated in a system that is useful for sampling mobile organisms. As mobile organisms cannot be sampled in plots, the options for within-site ecological studies for these species is limited. However, between-site differences may be more important for these groups. The trail system has allowed linetransect methods to be used for the endangered marmoset Saguinus bicolor, Owl communities, and Rose Wood (Aniba rosaeodora). Surveys along the trail system have revealed the presence of Harpy Eagles (Harpya harpyja) and Spider Monkeys (Ateles paniscus) that were thought to be extinct within the reserve. The $144 \mathrm{~km}$ of trails at Reserva Ducke have only just begun to be exploited for studies of organisms that occur at densities too low to be studied in plots.

The financial cost of installing the plot system we have described is much greater than that of installing randomly distributed plots as were originally used by Gentry. However, the costs are moderate, and very low considering the total output of the integrated studies. Installation of the system at Reserva Ducke was done exclusively with Brazilian financing, and the total cost to date for installation and surveys of plants, invertebrates, fish, and terrestrial vertebrates, and estimates of stocks and fluxes of above-ground arboreal biomass (excluding salaries of permanent staff and scholarships for graduate students) does not exceed US\$300.000. This includes the costs of hiring the staff that did most of the marking and measurement of plants, and collection of botanical material. Running costs to maintain access trails and field camps are less than US\$ 2.000 per year, and there is no difficulty in finding systematists and ecologists who bring their own resources to study the system. The infrastructure has attracted international researchers that use small very expensive plots for international comparisons, such as Conservation International's TEAM project, and the CTFS 50-ha plot project. In the long term, these intensive studies within the site will allow evaluation of scale-dependent differences in ecological processes, and the effects of sampling scale on biogeographical comparisons.
Our next challenge is to install similar systems throughout Amazonia. The cost, based on modification of Al Gentry's original design is moderate (less than US\$ 50.000 per site if it is not necessary to immediately identify all vascular plants in plots) and we can obtain RAP results for most taxa in the short term at much lower cost. However, biological surveys will only be relevant if the local people participate and the surveys serve as much to teach the local communities about the value of their natural resources as they serve to teach the international community about biodiversity. Therefore, we want to see each site run as a long-term ecological research project by local people and institutions. Biological surveys are an important tool in land-use planning, but only the local people can implement those plans.

\section{ACKNOWLEDGEMENTS}

Implementation of the trail and plot system, and all biological surveys were financed by CNPq. Scholarships for post-graduate students were provided by CNPq and CAPES.

\section{LITERATURE CITED}

CASTILHO, C. 2004. Variação espacial e temporal da biomassa arbórea viva em $64 \mathrm{~km}^{2}$ de floresta de terrafirme na Amazônia central. Tese de doutorado, INPA/ UFAM, Manaus.

CAUGHLEY, G. J. \& SINCLAIR, A. R. E. 1994. Wildlife Ecology and Management. Blackwell Scientific Publications, Oxford.

CLARK, D.B., PALMER, M. W. \& CLARK, D. A. 1999. Edaphic factors and the landscape-scale distributions of tropical rain forest trees. Ecology 80:2662-2675.

GENTRY, A. H. 1982. Patterns of Neotropical plant species diversity. Evol. Biol. 15:1-84.

HIRZEL, A. H., HAUSSER, J., CHESSEL, D. \& PERRIN, N. 2002. Ecological-niche factor analysis: how to compute habitat-suitability maps without absence data. Ecology 83:2027-2036.

KINUPP, V.F. \& MAGNUSSON, W.E. (in press) Spatial patterns in the understorey genus Psychotria in central Amazonia: effects of distance and topography. J. Trop. Ecol.

MAGNUSSON, W. E., CAUGHLEY, G. J. \& GRIGG, G. C. 1978. A double survey estimate of population size from incomplete counts. J. Wildl. Manage. 42:174-176.

MAGNUSSON, W. E. \& G. MOURÃO. 2004. Statistics Without Math. Editora Planta, Londrina. 
MARGULES, C. R. \& PRESSEY, R. L. 2000. Systematic conservation planning. Nature 405:243-253.

MENDONÇA, F. P. 2002. Ictiofauna de igarapés de terra firme: estrutura das comunidades de duas bacias hidrográficas, Reserva Florestal Adolpho Ducke, Amazônia Central. Dissertação de mestrado, INPA/ UFAM, Manaus.

MEOT, A. , LEGENDRE, P. \& BORCARD, D. 1998. Partialling out the spatial component of ecological variation: questions and propositions in the linear modelling framework. Envir. Ecol. Stat. 5:1-27.

NICHOLS, J. D., BOULINIER, T., HINES, J. E., POLLOCK, K. H. \& SAUER, J. 1998. Estimating rates of local species extinction, colonization, and turnover in animal communities. Ecol. Appl. 8:1213-1225.

PHILLIPS, O. L., MARTÍNEZ, R. V., VARGAS, P. N., MONTEAGUDO, A. L., ZANS, M.-E. C., SÁNCHEZ, W. G., CRUZ, A. P., TIMANÁ, M., YLI-HALLA \& ROSE, S. 2003. Efficient plot-based floristic assessment of tropical forests. J. Trop. Ecol. 19:629-645.

RIBEIRO, J. E. L. S., HOPKINS, M. J. G., Vicentini, A., SOTHERS, C.A,COSTA, M.A. S., BRITO, J. M., SOUZA, M. A. D., MARTINS, L. H. P., LOHMANN, L. G., ASSUNÇÃO, P.A. C. L., PEREIRA, E. C., SILVA, C. F., MESQUITA, M. R. \& PROCÓPIO, L. 1999. Flora da Reserva Ducke: Guia de Identificação das Plantas Vasculares de uma Floresta de Terra Firme na Amazônia Central. INPA/DFID, Manaus, Brasil.

REDDY, S. \& DÁVALOS, L. M. 2003. Geographical sampling bias and its implications for conservation priorities in Africa. J. Biogeogr. 30:1719-1727.

REYERS, B., FAIRBANKS, D. H. K., WESSELS, K. J. \& VAN JAARSVELD, A. S. 2002. A multicriteria approach to reserve selection: addressing long-term biodiversity maintenance. Biodiversity Cons. 11:769-793.

STERN, M. J. 1998. Field comparisons of two rapid survey vegetation assessment techniques with permanent plot inventory data in Amazonian Peru. In Forest Biodiversity Research, Monitoring and Modelling (Dallmeier, F. \& J. A. Comiskey, eds). UNESCO \& Parthenon Publishing, Paris, p. 269-283.

TUOMISTO, H. \& RUOKOLAINEN, K. 1994. Distribution of Pteridophyta and Melastomataceae along an edaphic gradient in an Amazonian rain forest. J. Veg. Sci. 5:25-34.

TUOMISTO, H., POULSEN, A. D., RUOKOLAINEN, K., MORAN, R. C., QUINTANA, C., CELI, J. \& CANÃS, G. 2003. Linking floristic patterns with soil heterogeneity and satellite imagery in Ecuadorian Amazonia. Ecol. Appl. 13:352-371.

VORMISTO, J., PHILLIPS, O. L., RUOKOLAINEN, K., TUOMISTO, H., \& VASQUEZ, R. 2000. A comparison of fine-scale distribution patterns of four plant groups in an Amazonian rainforest. Ecography 23:349-359.
Title: RAPELD: a modification of the Gentry method for biodiversity surveys in long-term ecological research sites.

Authors: William E. Magnusson, Albertina P. Lima, Regina Luizão, Flávio Luizão, Flávia R. C. Costa, Carolina Volkmer de Castilho and V. F. Kinupp.

Biota Neotropica, Vol. 5 ( number 2): 2005

http://www.biotaneotropica.org.br/v5n2/pt/ abstract?point-of-view+bn01005022005

Date Received 09/17/2004 - Revised 06/26/2005

Accepted 07/01/2005

ISSN 1676-0611 